\title{
SPATIAL-TEMPORAL EVOLUTION CHARACTERISTICS AND TRENDS OF GROUNDWATER LEVEL IN THE PEOPLE'S VICTORY CANAL IRRIGATION DISTRICT, CHINA
}

\author{
LIU, Z. P. ${ }^{1,2}-$ SHI, Y. ${ }^{1}-$ ZHAO, Y. T. ${ }^{1}-$ HAN, Y. P. ${ }^{1 *}-$ NIU, X. T. ${ }^{3}$ \\ ${ }^{1}$ Department of Water Resources, North China University of Water Resources and Electric \\ Power, Zhengzhou 450045, China \\ ${ }^{2}$ China Institute of Water Resources and Hydropower Research, Beijing 100038, China \\ ${ }^{3}$ Xinzheng Coal and Electricity Co., Ltd, Xinzheng 450000, China \\ *Corresponding author \\ e-mail: Hanyp@ncwu.edu.cn \\ (Received 22 $2^{\text {nd }}$ Jul 2016; accepted $9^{\text {th }}$ Nov 2016)
}

\begin{abstract}
Based on the observational data of the groundwater depth between 1993 and 2013, this paper analyzes the spatial-temporal evolution characteristics and trends of groundwater level in the People's Victory Canal Irrigation District of China by using the ARCGIS and SPSS platform and the methods including Kriging, IDW interpolation method and Spearman rank correlation analysis. Research results show that: the groundwater level overall displays an inter-annual declining trend and the areas of declining water level are gradually increasing, which constantly increases the accumulated declining range of water level. Compared with the groundwater level in 1993, the areas of declining water level increase from $1483 \mathrm{~km}^{2}$ in 2000 to $1824 \mathrm{~km}^{2}$ in 2013. In 2000 and 2005, the maximum declining range of the groundwater level is $0 \sim 2 \mathrm{~m}$ and they account for $53.01 \%$ and $69.12 \%$ of the total area respectively, while the situation changes between 2010 and 2013: The 2 4 m declining range has replaced the dwindling $0 \sim 2 \mathrm{~m}$ area as the main trend and the declining ranges increase to $60.05 \%$ and $59.38 \%$ of the total area respectively. $55 \%$ of the total observational sites display a dramatic decline in the groundwater level, $47 \%$ of which shows a highly dramatic decline. Areas of rising water level are sporadically distributed in the southwestern part of the irrigation area and the remaining $43 \%$ of observational sites show few signs of fall or rise in the groundwater level.
\end{abstract}

Keywords: groundwater depth; groundwater evolution; spatial-temporal differentiation; spearman rank correlation analysis

\section{Introduction}

Groundwater, as an important part of the water resources, plays a crucial role in guaranteeing the water demands in urban and rural households and maintaining the socio-economic development and ecological balance. Moreover, the groundwater resources cannot be replaced particularly in areas where the surface water resources are relatively in shortage. With the increasingly dramatic influence of human activities on the water circulation, new and special evolution rules are derived in the dynamic changes of the groundwater level. A lot of studies have been conducted on the features, reasons and various problems of the groundwater changes by domestic and foreign scholars. Reilly (1996) analyzes the features of groundwater in areas of relatively independent water resources transformation and reveals the artificial controllability of the groundwater level. Tembezeka et al. (1997) describes the interaction between the change features of the groundwater and land utilization rate. Yan et al. (2014) study the features and mechanisms of the groundwater level changes in the central part of 
Zhangye Basin. Zhou et al. (2009) analyze the changes of the groundwater level and the influence of land use on the groundwater level. Yang et al. (2003) conduct the quantitative analysis on the influence of human activities on the ground water regime through using the GIS technology.

Located in the upper section of the downstream Yellow River, the People's Victory Canal Irrigation District has good conditions for water diversion. With a development history of over 50 years, the irrigation district has developed from the original agricultural gravity irrigation into a multi-functional water district meeting the demands of the rural and urban industry as well as the households (Wang, 2004). As the society and the economy develop, the water consumption increases in various regions and departments, so the gap between supply and demand for the Yellow River water resources increasingly widens. The water diversion quantity is limited in the People's Victory Canal Irrigation District and people even compete for water in some areas, which increases the amount of groundwater exploitation. Therefore, this paper helps to reveal the differences in the changes of the regional groundwater level and provides important evidence for the rational utilization of surface water and groundwater resources as well as the optimal allocation of water resources in the irrigation district by studying the spatial-temporal differentiation evolution characteristics and trends of groundwater level.

\section{Data and methods}

\section{General situation of research area}

Situated in the north bank of the Yellow River, the People's Victory Canal Irrigation District has Wei River and South Changhong Canal to the north; and Shi Village in Yuanyang County, Langgong Temple in Xinxiang City, Yulin Town in Yanjin County, and Qi Village in Hua County to the south; and Wujia Irrigation District and the Communism Canal as the boundary to the west; and adjoins with the Red Flag main canal to the east, as shown in Fig. 1. Influenced by the flood sediments of the Yellow River in the past, three geomorphic units are formed in the irrigation district with the ancient Yellow River deserted dyke (Guyang Dyke) as the boundary: ancient Yellow River overflow area, ancient Yellow River depression area and Wei River sediment area. The groundwater flow direction corresponds with the slope aspect of the ground, namely from southwest to northeast. The groundwater contains two aquifers in the irrigation district. The first one is the shallow unconfined aquifer with the floor depth of 40 60 m, and mainly contains silty-fine sand, medium sand and coarse sand without steady and continuous clay or mid clay water-resisting layer inside the stratum. The other is the deep confined aquifer with the floor depth of $90 \sim 110 \mathrm{~m}$ and the lithology features the medium-fine sand with bits of ginger nuts. The irrigation district belongs to the temperate continental monsoon climate with distinct four seasons. The rainfall is unevenly distributed throughout the year and the multi-year average rainfall is 581.2 $\mathrm{mm}$, an obvious combination of drought and flood. Main rivers include Wei River, East Mengjiangnv River and West Mengjiangnv River, among which Wei River, the main drainage receiver, is located in the north of the irrigation district. The land covers an area of $1486.84 \mathrm{~km}^{2}$ in the planning area of the irrigation district and the staple crops include wheat, corn, rice, cotton, rape seed, peanuts etc. As the crop rotation farming method is adopted in most districts, crops such as wheat, corn, peanuts and rice can be harvested twice within a year. The seeded area is 150.8 thousand ha. 

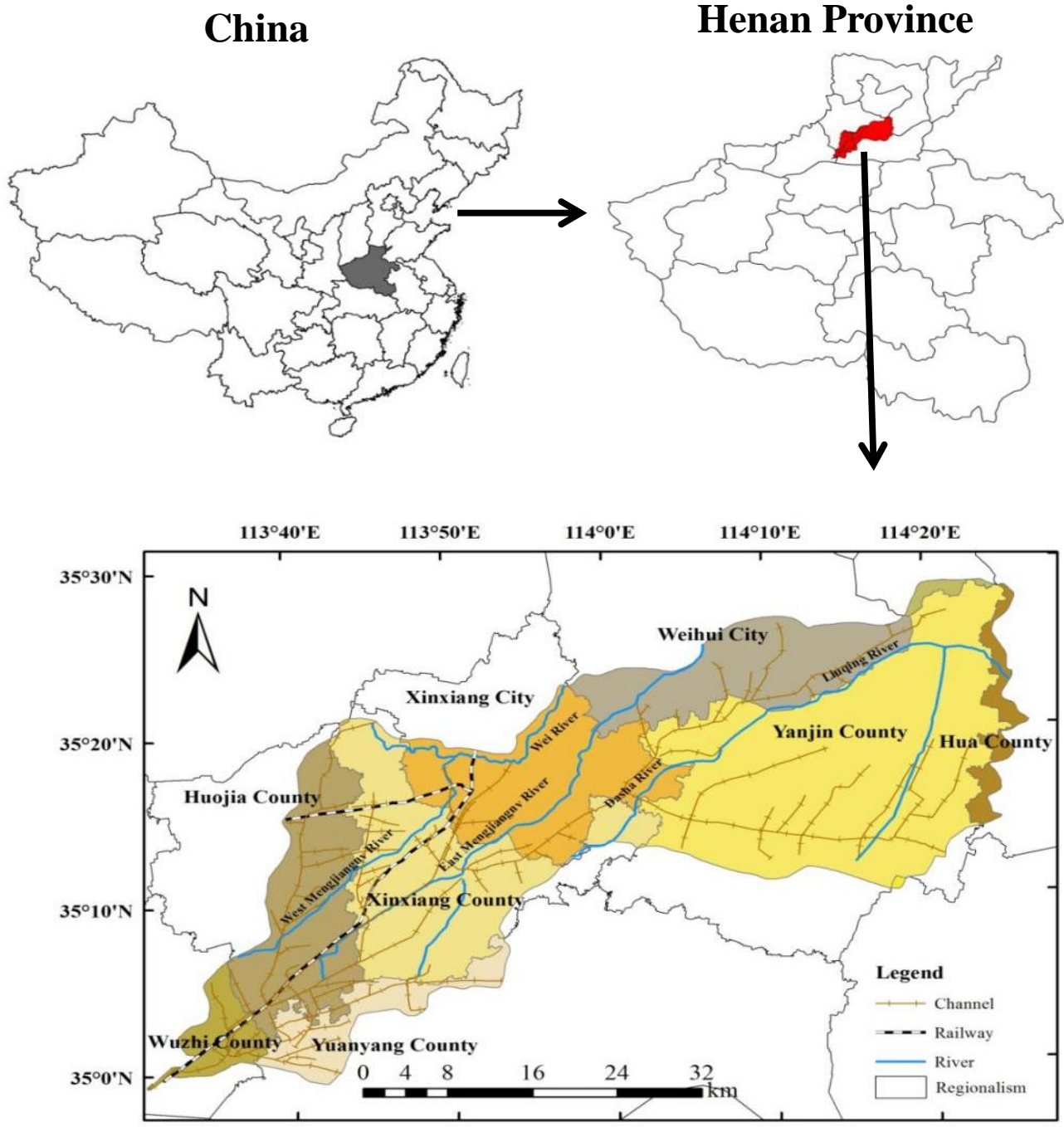

Figure 1. The location of the People's Victory Canal Irrigation District of China

\section{Data sources and methods}

This paper selects the data for the monthly and annual average groundwater depth collected from 58 observation wells of the People's Victory Canal Irrigation District from 1993 to 2013. The analysis of the time series changes for the groundwater level is conducted by drawing the curves for its annual average depth in the irrigation district as well as the curves for its annual depth in the wet, normal and dry years. Based on the background value of the groundwater level in 1993, this paper first draws the grid map of the water level variation during different periods in 2000, 2005, 2010 and 2013 by using the ARCGIS software and the Kriging interpolation method (Su et al., 2004) and then obtains the spatial distribution of the water level variation during different periods in the irrigation district in order to analyze the spatial variability characteristics of the groundwater level. Subsequently, the Spearman rank correlation method is used to calculate the correlation coefficient of the groundwater level in relation to time in 58 observation wells of the irrigation district. 
Spearman Rank Correlation Analysis method is used to analyze the correlation between two variables, of which one variable is in time series at least. It is simple and accurate, calculated as following,

$$
r_{s}=1-\frac{6 \sum_{i}^{n} D_{i}^{2}}{N^{3}-N}
$$

Where $r_{s}$ is Spearman Rank Correlation coefficient, $D_{i}$ is the difference between the rank of $y_{i}$ and the rank of $x_{i}, y_{i}$ is the ith observation value of variable $\mathrm{Y}$ and $x_{i}$ is the ith observation value of variable $\mathrm{X}, \mathrm{N}$ is sample size.

If $r_{s}<0$, it indicates that groundwater level displays an inter-annual declining trend, and if $r_{s}>0$, it shows that groundwater level displays and increasing trend.

Meanwhile, the IDW interpolation method is used to determine the trends of the groundwater level changes and the spatial distribution of the correlation coefficient based on the ARCGIS platform (Li et al., 2000; Jin et al., 2009; Chen, 2011; Jiang, 2013; Liu et al., 2013; Liu, 2013; Li et al., 2015; Ge et al., 2015; Yu et al., 2015; Yu et al., 2016).

\section{Results and discussion}

\section{Situations of the groundwater flow field}

The groundwater generally flows from the southwest to the northeast in the irrigation district. The maximum groundwater level is distributed at the mouth of water diversion in the floodplain of the southwestern Yellow River and the annual average groundwater depth is approximately $4 \mathrm{~m}$, while the minimum groundwater level is located in the northeastern part of the irrigation district and the annual average groundwater depth is approximately 9 m, as shown in Fig. 2.

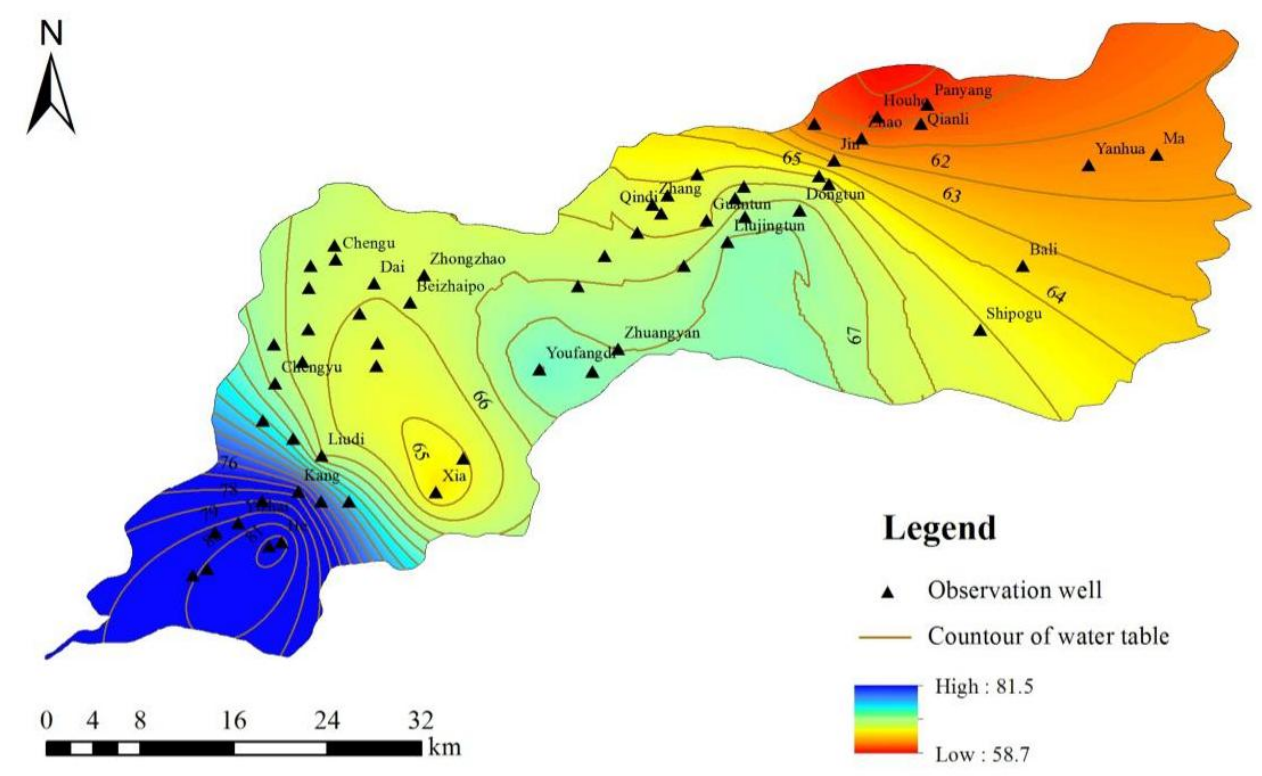

Figure 2. Groundwater flow field in the irrigation district 


\section{Temporal evolution characteristics of groundwater level}

Fig. 3 shows the changes of groundwater depth in different locations of the irrigation district from 1993 to 2013. The groundwater level overall drops but the declining range differs in different locations of the irrigation district. The groundwater depth is relatively shallow in the southwestern part (Kang Village) of the irrigation district. A large supplementary amount of the groundwater field leakage is caused by the irrigation---drawing water from the Yellow River, so the groundwater level displays a trend of fluctuating rise before 2001 but it enters a stably declining stage after 2003 within a rather small range. No dramatic changes are detected in southern irrigation district (Xia Village) before 1999, but the depression cone of groundwater level is formed after and the groundwater depth increases rapidly because the groundwater exploitation accelerates in the industrial and agricultural irrigation. Thus, the groundwater depth increases from 7.0 $\mathrm{m}$ in 1999 to $14.6 \mathrm{~m}$ in 2003, and the groundwater level has decreased by $7.6 \mathrm{~m}$ within four years. The groundwater level enters a stably declining stage and the declining range gradually decreases since 2003. The trends of the groundwater level changes are approximately similar between the central part of the irrigation district (Liujing Village) and the eastern part of the irrigation district (Houhe Village), the groundwater level fluctuates before 2001, descends dramatically between 2001 and 2003, and enters a stably declining stage after 2003.
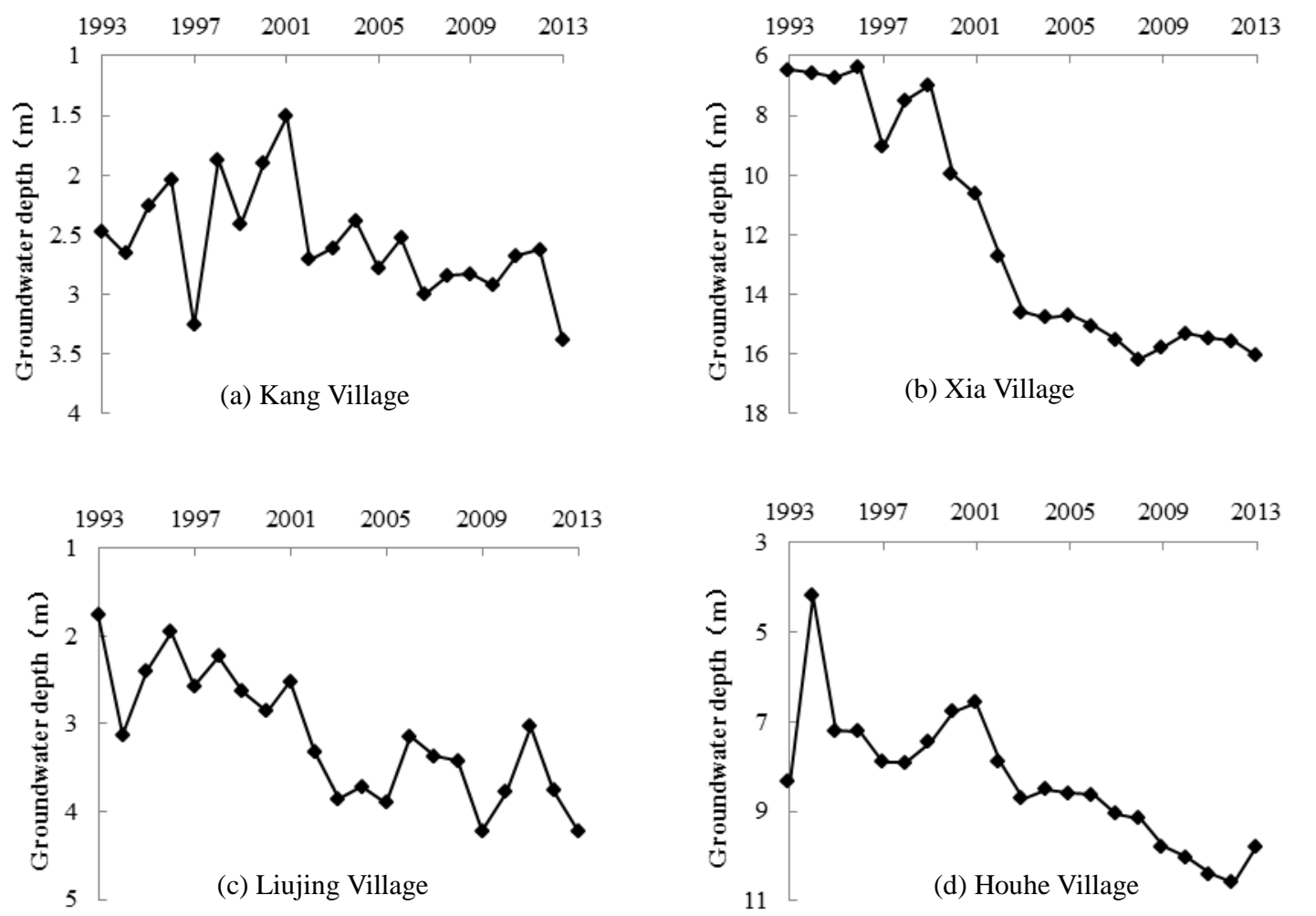

Figure 3. The variation of annual average groundwater depth

From the annual average groundwater depth trends in the wet, normal and dry years (Fig. 3), it can be seen that the type of the groundwater regime is artificial exploitation---rainfall infiltration. In the wet season, the rainfall increases and the supplemented groundwater increases correspondingly because of more rainfall 
infiltration. In addition, the summer-corns are mainly planted in the research area and the rainfall basically meets the water demands of the crops in the wet season, so the groundwater exploitation is relatively less in the irrigation, namely the wet season features more supplemented rainfall, less groundwater exploitation and the rising the groundwater level. In the dry season, the rainfall decreases and the supplemented groundwater decreases correspondingly because of less rainfall infiltration. On the other hand, the water-consuming winter wheat is mainly planted in the research areas, so the groundwater exploitation increases in the irrigation, especially in the critical growth stage (in March and April) of the winter wheat. Except some districts adopting the canal water irrigation, most districts are irrigated through the groundwater exploitation in spring, thus the groundwater level declines dramatically. That is, the supplemented groundwater through rainfall infiltration becomes less and the groundwater exploitation increases, which exacerbates the negative balance of the groundwater regime in terms of sources and goals and causes the groundwater level to decline dramatically.

The trends of the annual groundwater level in the wet, normal, dry year differ from each other mainly in the range and the time-scale effect of the groundwater level changes, as shown in Fig. 4. In the wet year, the groundwater level starts to increase in May and June and the increase range is relatively big. For example, in 2000 (the high flow year), the groundwater depth decreases from $5.18 \mathrm{~m}$ in May to $2.59 \mathrm{~m}$ in September with the groundwater level increasing by $2.59 \mathrm{~m}$, and the groundwater level increases by $1.85 \mathrm{~m}$ between June and July. The rainfall in the normal year is less than that in the wet year, so the supplemented groundwater decreases because of less rainfall infiltration and the groundwater level rises within a small range. In addition, the groundwater level rises in June and July, later than the time of the wet year. In the dry year, the rainfall is even less without the dramatic rise in the groundwater level. And the groundwater level even continuously declines.

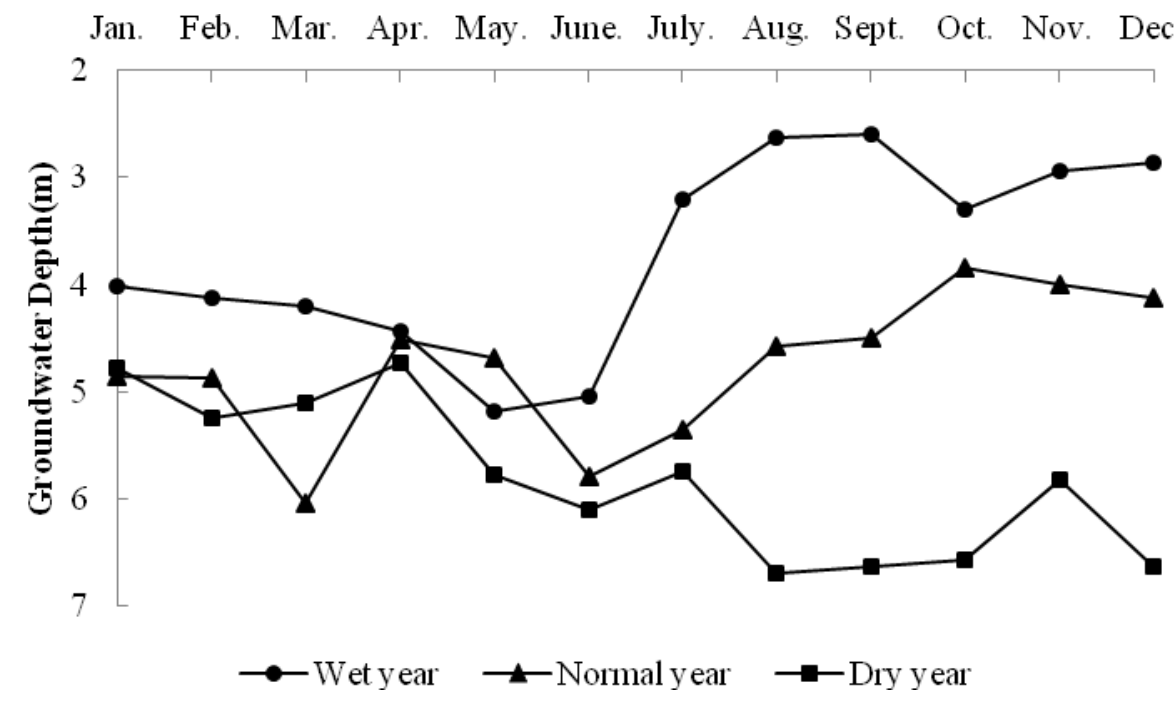

Figure 4. The variation of groundwater depth in wet, normal and dry years

\section{Spatial variability characteristics of the groundwater level}

Fig. 5 shows the spatial distribution characteristics of the groundwater level changes in the People's Victory Canal Irrigation District. Compared with the situation in 1993, the groundwater level rises in the southwestern part (He Village) and the northeastern 
part (Houhe Village and Qianli Village) of the irrigation district in 2000 and the rising range is between $0 \sim 4 \mathrm{~m}$, which accounts for $27.15 \%$ of the total irrigation area. These districts above are named the rise area of groundwater level. The decline area of groundwater level extends from the southern Kang Village to the northern Liu Village. In this part, the 0 4 $\mathrm{m}$ decline range covers the largest area and accounts for $64.2 \%$ of the total irrigation area. The maximum decline range of the groundwater level is founded in the semi-closed water level decline area that extends northward with Xia Village as the centre point. The groundwater level decline range is $4 \sim 16 \mathrm{~m}$ here, accounting for $8.65 \%$ of the total irrigation area, where the $12 \sim 16 \mathrm{~m}$ decline range makes up $0.36 \%$ of the $4 \sim 16 \mathrm{~m}$ range.

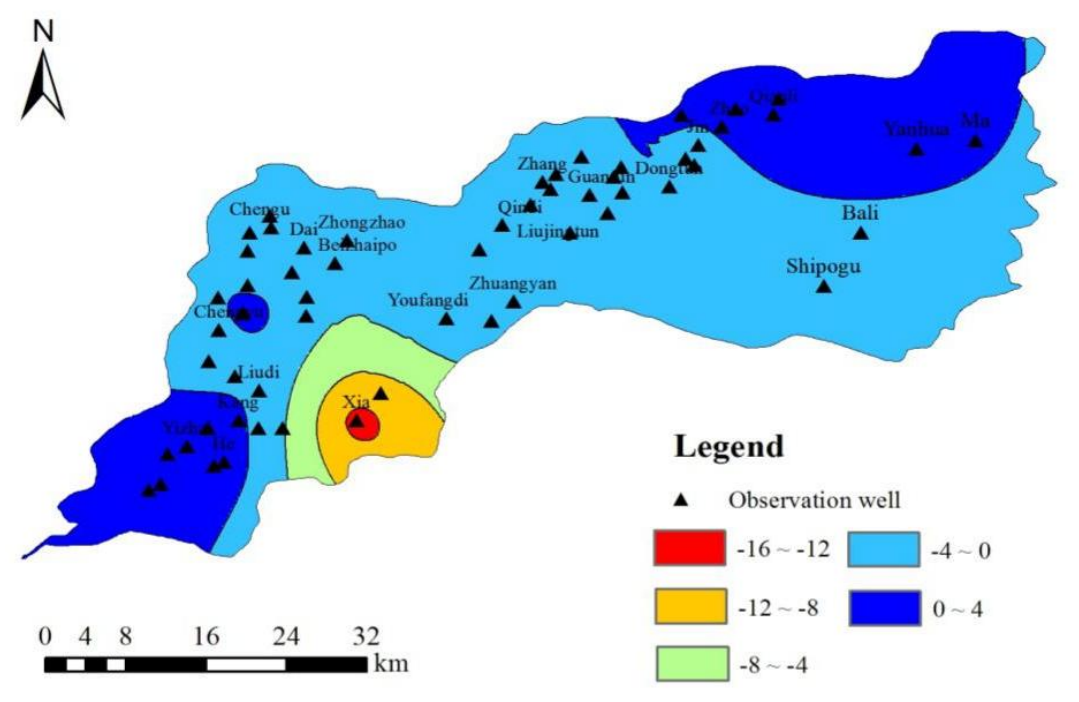

(a) $1993 \sim 2000$

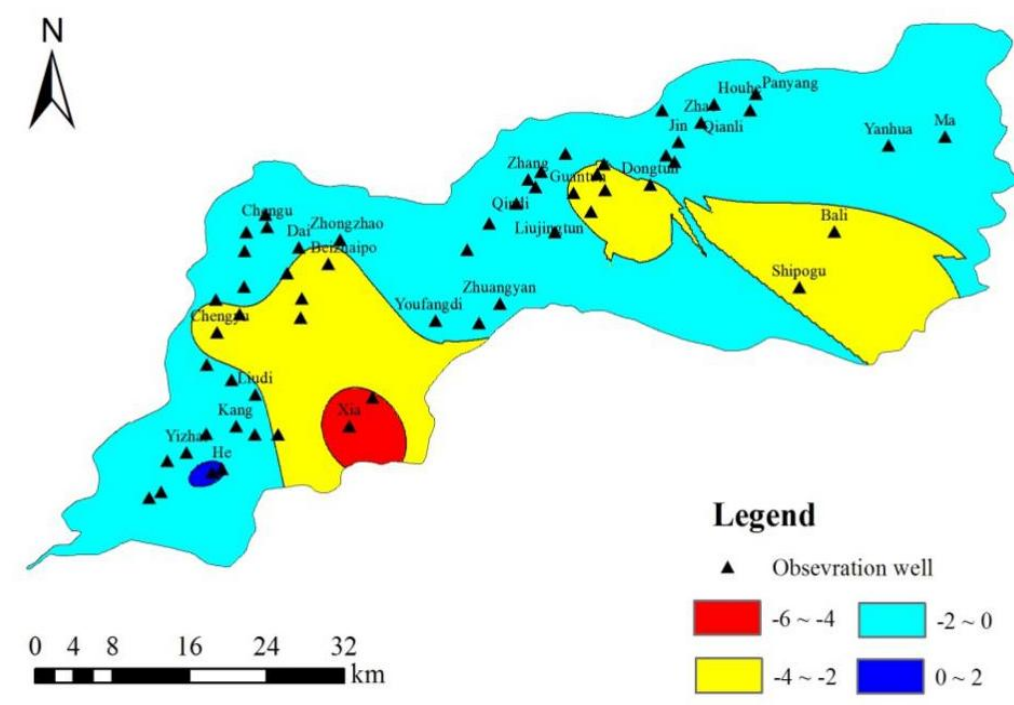

(b) 1993 2005 


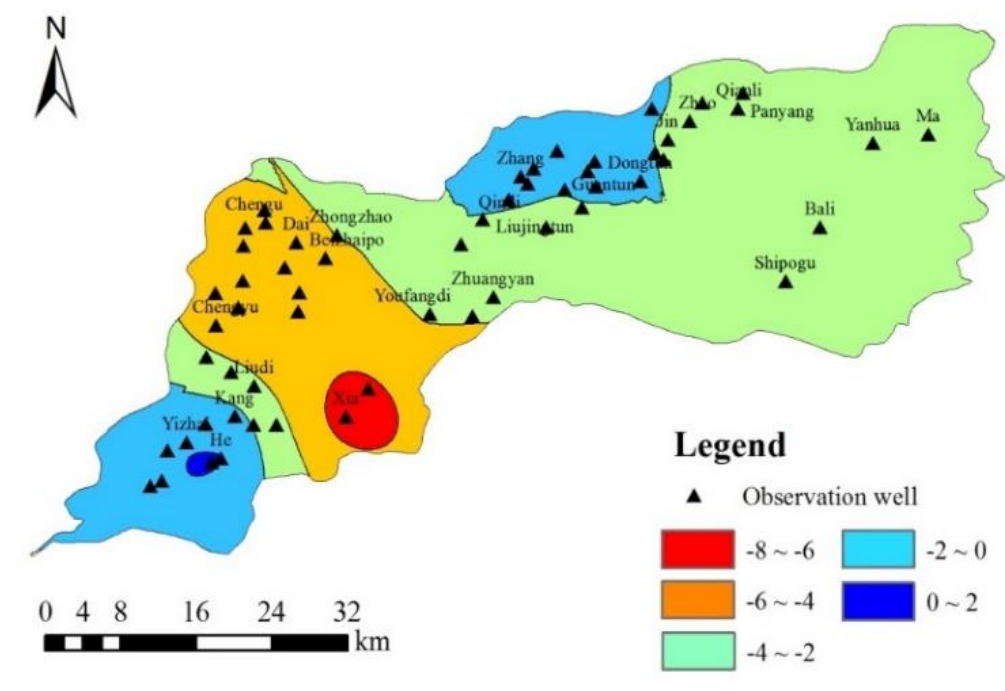

(c) $1993 \sim 2010$

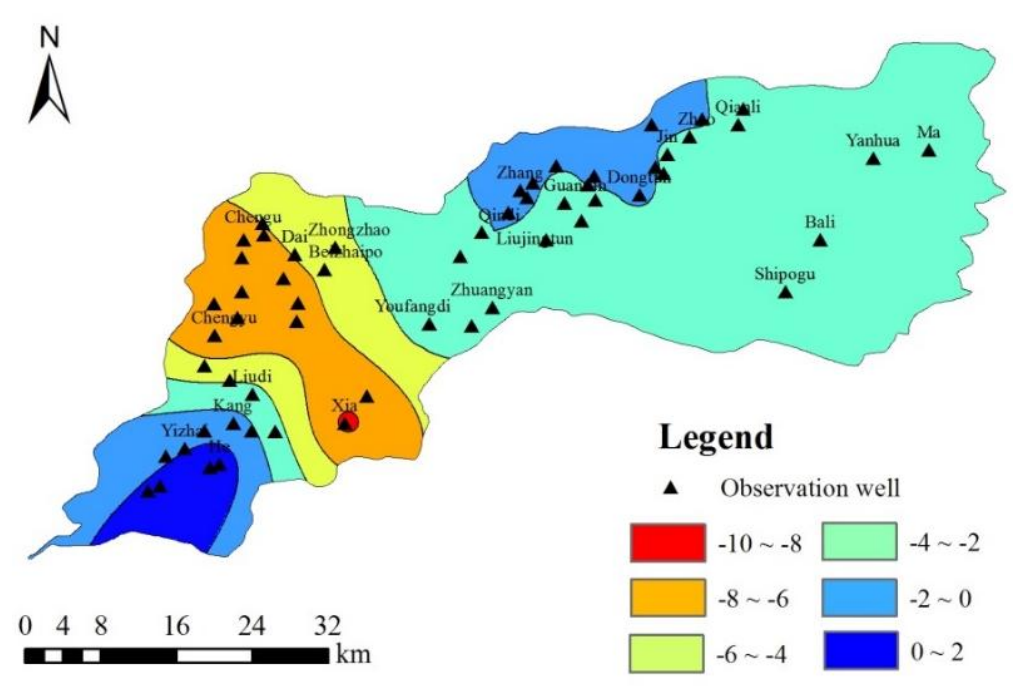

(d) $1993 \sim 2013$

Figure 5. The spatial distribution of groundwater table changes in 1993 2000, 1993 2005, 1993 2010 and 1993 2013

Compared with the situation in 1993 , only $0.31 \%$ of the total irrigation district nearby He Village belongs to the groundwater level rise area in 2005 and its rise range is $0 \sim 2 \mathrm{~m}$. The southwest, north and east of the irrigation district accounts for $69.12 \%$ of the total irrigation area and their decline range of groundwater level is $0 \sim 2 \mathrm{~m}$. The decline range of groundwater level is $2 \sim 4 \mathrm{~m}$ in the central part (Chengyu Village and North Zhaipo Village) and the eastern part (Liujin Village and Xiao Village), which accounts for $28.29 \%$ of the total irrigation area. The areas nearby Xia Village still 
features the maximum decline range of groundwater level with its decline range at 4-6 $\mathrm{m}$ and these areas account for $2.28 \%$ of the total area.

Compared with the situation in 1993, the groundwater level rises by 0 2 m only in areas nearby He Village in 2010, which accounts for $0.31 \%$ of the total irrigation district. The groundwater level drops by $0 \sim 2 \mathrm{~m}$ in the southwestern part (Yi Village and He Village) and the northern part (Zhang Village and Qindi Village) and these areas account for $18.17 \%$ of the total irrigation district. The groundwater level drops by $2 \sim 4 \mathrm{~m}$ in Kang Village nearby He Village and most of the eastern part of the irrigation district, accounting for $60.05 \%$ of the total irrigation district. The areas nearby Xia Village still has the maximum decline range of groundwater level $6 \sim 8 \mathrm{~m}$ and they account for $2.02 \%$ of the total irrigation district. The groundwater level decreases by more than $4 \mathrm{~m}$ in Chengyu Village and North Zhaipo Village to the north of Xia Village.

Compared with the situation in 1993, the groundwater level rises by $0 \sim 2 \mathrm{~m}$ near The Village located in the southwestern irrigation district and this area accounts for $4.25 \%$ of the total area. The groundwater level drops by $2 \sim 6 \mathrm{~m}$ in areas extending from Kang Village in the western part, Zhongzhao Village and Youfangdi Village in the central part to northeastern part of the irrigation district and these areas account for $69.9 \%$ of the total irrigation area. Among these districts, the groundwater level drops by $2 \sim 4 \mathrm{~m}$ in Kang Village and most of the eastern parts, and these districts account for $59.38 \%$ of the total irrigation area. The groundwater level decreases by more than $6 \mathrm{~m}$ in $12.76 \%$ of the areas extending from Xia Village to Chengyu Village. Moreover, the groundwater level which decreases by $6 \sim 8 \mathrm{~m}$ accounts for $12.8 \%$ of the total areas in Xia Village and Chengyu Village.

It can be seen in Fig. 5 that: compared with the situation in 1993, the groundwater level generally decreases in most parts of the irrigation district except in the southwestern part and northeastern part in 2000 where the groundwater level slightly drops or rises. These changes are closely related with factors including the quantity of water diversion, rainfall, irrigation-related groundwater exploitation, irrigation methods and water consumption etc. in the irrigation district. The groundwater level slightly drops or rises in the southwestern irrigation district mainly because this district is near the head works of the People's Victory Canal, making it convenient to get water and guaranteeing the efficiency of water diversion. In addition, the rice is planted in this district and is mainly irrigated by the water drawn from the Yellow River, so the supplementary amount of field leakage for the groundwater is considerable. In 2000, the rise in the groundwater level is mainly related with the rainfall of the year in the irrigation district and the annual rainfall is $863.4 \mathrm{~mm}$, which is $48.6 \%$ more than the multi-year average rainfall of $581.2 \mathrm{~mm}$. Coupled with its location near the Wei River to the north, the supplementary amount of the groundwater gets increased. The midstream and downstream sections of the irrigation basin belong to the depression part of the ancient overflow area and the Wei River sediment area, so the irrigation methods are divided into the well-canal combination and the well irrigation. As the groundwater exploitation increases in the agricultural irrigation, the middle and central parts are generally greater than the western part in the decline range of groundwater level. The groundwater depression cone is formed in the areas nearby Xia Village because of the agricultural groundwater exploitation and the industrial water consumption in the local paper mills. Worse, the groundwater level increasingly decreases in the depression cone and the areas of groundwater level decrease are gradually expanding to the northern Chengyu district.

The acreage of the increasing groundwater level decreases in the research area, while the acreage of the dropping groundwater level increases as shown in Fig. 5. Based on the background value of the groundwater level in 1993, the acreage of the increasing 
groundwater level dwindles from $404 \mathrm{~km}^{2}$ in 2000 to $63 \mathrm{~km}^{2}$ in 2013 , where the acreage of the increasing groundwater level dwindles to $4 \mathrm{~km}^{2}$ and $5 \mathrm{~km}^{2}$ in 2005 and 2010 respectively. With the decrease in the acreage of the rising groundwater level in the irrigation district, the acreage of the dropping groundwater level gradually enlarges. Fig. 6 shows the changes about the acreage of the dropping underground water level in relation to the declining range of the groundwater level during different periods. Compared with the situation in 1993, the total area of the declining groundwater level is $1083 \mathrm{~km}^{2}$ in 2000 and the areas with the $0 \sim 2 \mathrm{~m}$ declining range covers the largest area $-788 \mathrm{~km}^{2}$. The acreage of the declining groundwater level is $1483 \mathrm{~km}^{2}$ in 2005 and the area with the $0 \sim 2 \mathrm{~m}$ declining range reaches $1028 \mathrm{~km}^{2}$. The areas of the declining groundwater level are $1482 \mathrm{~km}^{2}$ and $1424 \mathrm{~km}^{2}$ in 2010 and 2013 respectively, but the acreage with the 0 2 $\mathrm{m}$ declining range decreases and the $2 \sim 4 \mathrm{~m}$ declining range has become the main trend with the corresponding acreage increasing to $893 \mathrm{~km}^{2}$ and 883 $\mathrm{km}^{2}$ respectively.

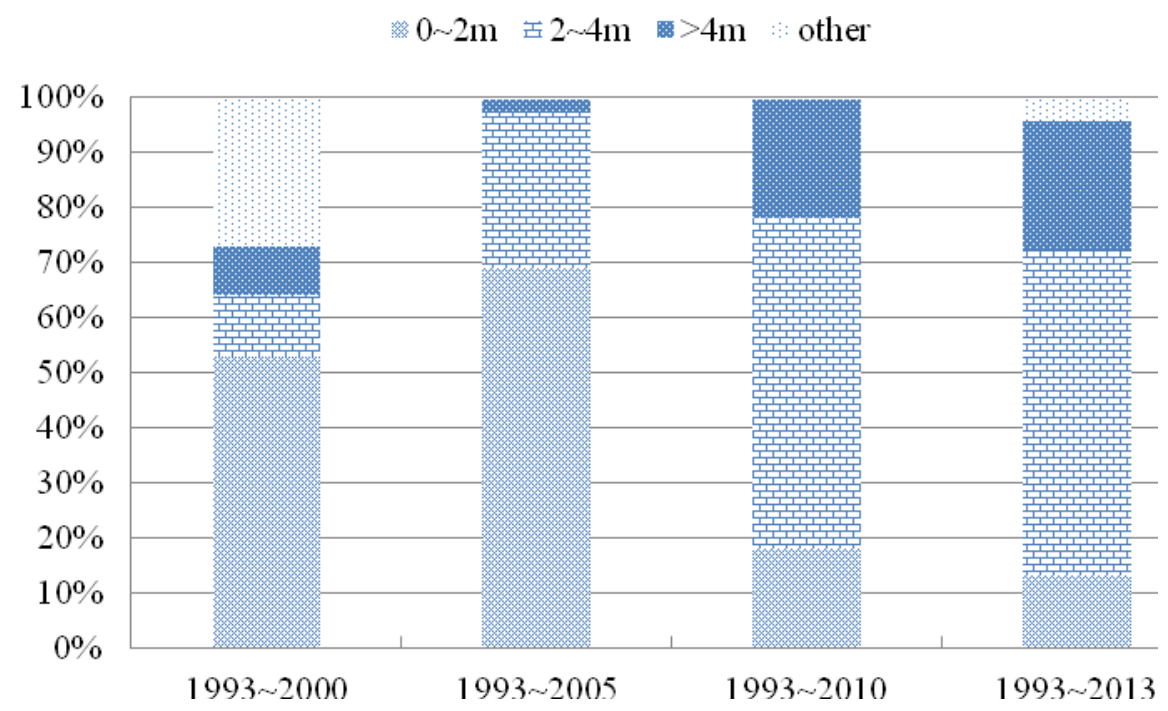

Figure 6. Changes about the acreage of the dropping groundwater level in relation to its declining range in different periods

\section{Evolution trends of the groundwater level}

The SPSS software is used as the platform to calculate the variation trends of the annual average water level sequences for the observation wells of the irrigation district and the ARCGIS software is also used for drawing the variation trend diagram for all the observation wells. The results of Spearman rank correlation analysis are shown in Fig. 7.

According to the results of Spearman rank correlation analysis for 58 observation wells, the groundwater level without obvious rise or drop trends accounts for $43 \%$, and that with dramatic decline makes up 55\% (pass the significance testing of $\alpha=0.05$ ), where the groundwater level of $47 \%$ sites pass the significance testing of $\alpha=0.01$, indicating an obvious decline trend. Only $2 \%$ of the sites display the rising trend in the groundwater level.

The northern part, eastern part and the Xia village near the southern part of the irrigation district all display a dramatic decrease trend in the groundwater level, and the correlation coefficient about the groundwater depth in relation to the time changes basically ranges from -1 to -0.5 , which is of significant correlations. In these districts, 
the groundwater level decreases dramatically mainly because the well irrigation is mainly used in the agricultural irrigation and the groundwater exploitation is relatively large in quantity. No dramatic rise or drop trend of the groundwater level is found in the western part and the northern rim of the central part in the irrigation district and the correlation coefficient basically ranges from 0 to 0.5 . This is because the western part of the irrigation district is located in the upstream section of the water diversion canal, guaranteeing the efficiency of the water diversion and the northern rim of the central part is close to Wei River, where the agricultural production all relies on the canal irrigation with relatively small groundwater exploitation. In the western part of the irrigation district lie some sporadic districts with the rising groundwater level, such as Xiaodong Village, Yi Village etc. mainly because the canal-system leakage supply and the field irrigation infiltration supplement the groundwater.

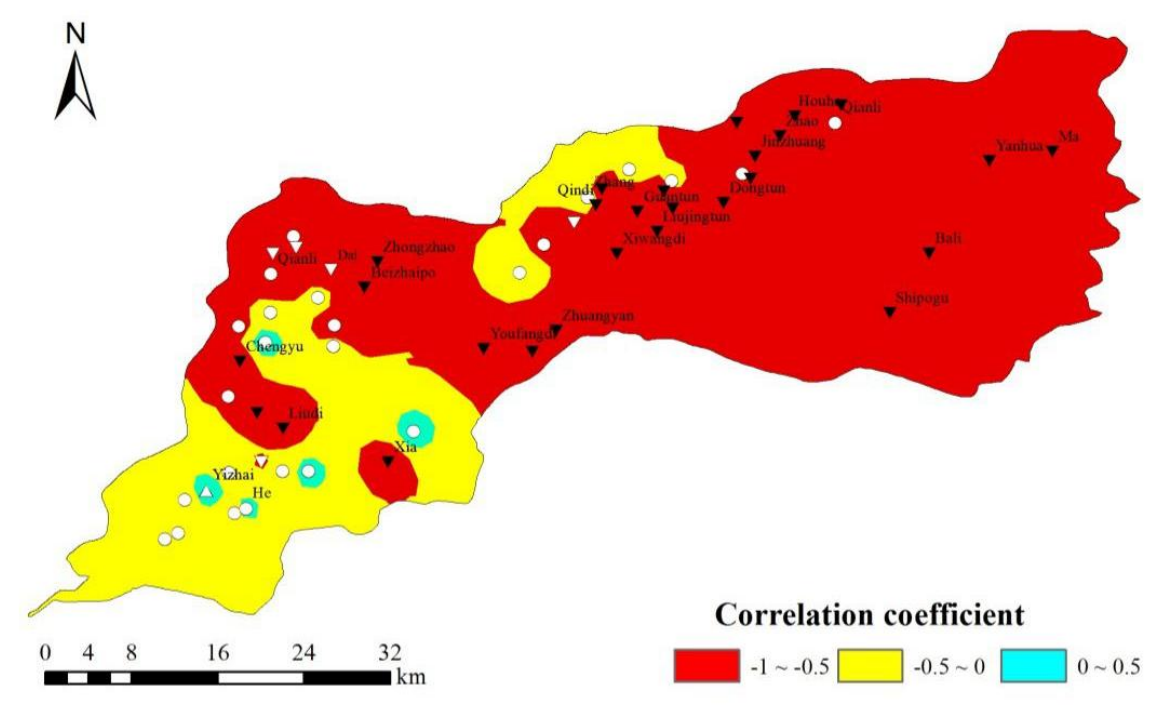

Figure 7. Evolution trends of groundwater level and the distribution of the correlation coefficient

\section{Conclusions}

The groundwater level generally displays a trend of annual decline in the research area, but the yearly declining range of the groundwater level differs in different locations of the irrigation district. The type of groundwater regime is artificial exploitation - rainfall infiltration. Because of the increasing groundwater exploitation amount and the declining rainfall, the groundwater level gradually decreases in the dry period until it reaches the minimum groundwater level in the wet period. In the wet period, the less groundwater exploitation and the more rainfall cause the groundwater level to increase.

The acreage of the rising groundwater level displays a declining trend in the research area, while the acreage of the declining groundwater level shows a rising trend. In addition, the accumulated declining range of the groundwater level continuously increases. Based on the background value of the groundwater level in 1993, the maximum declining range of the groundwater level ranges from $0 \sim 2 \mathrm{~m}$ in 2000 and 2005, and the corresponding areas account for $53.01 \%$ and $69.12 \%$ of the total area, while the acreage with the 0 2m declining range decreases in 2010 and 2013 and the 2 4m 
declining range has become the main trend, with the corresponding acreage increasing to $60.05 \%$ and $59.38 \%$ of the total area.

The observation sites with dramatic decline in the groundwater level account for $55 \%$ of the total sites, where $47 \%$ observation sites has a rather dramatic decrease in the groundwater level. The districts with the rising groundwater level are sporadically distributed in the southwestern irrigation district and the remaining $43 \%$ observation sites show no dramatic rise or drop trends of the groundwater level. The observation sites with dramatic declining trends are basically distributed in the zone of the relatively large negative correlation coefficient, while those sites with no dramatic changes or rising trends are basically distributed in the zone of the relatively small negative correlation coefficient or positive correlation coefficient.

Acknowledgements. This study was supported by the National Natural Science Foundation of China (Grant No. 51209090 and 71271086), Outstanding youth project of science and technology innovation in Henan Province (Grant No. 201411).

\section{REFERENCES}

[1] Reilly, T. E. (1996): Source of water to wells for transient cyclic systems. - Ground water 34(6): 979-988.

[2] Tembezeka, M. P., Andrew, S. A. J. (1997): Appiah S. O. Ground water management in drought-prone areas of Africa. - Water Re-sources Development 13(2): 241-261.

[3] Yan, Y. X., Wang, S. J., Yan, M., et al. (2014): Temporal spatial variations of the groundwater level and its mechanism analysis for middle part of Zhangye basin. - Journal of Arid Land Resources and Environment 28(11): 90-97.

[4] Zhou, J., Li, X., Wang, G. X., et al. (2009): The spatio-temporal variation analysis of groundwater and response to land-use change in the middle reaches of the Heihe River Basin. - Journal of Natural resources 24(3): 498-906.

[5] Yang, J. Q., Luo, X. X., Gao, Z. H. (2003): Quantitative analysis on impacts of human activities on the groundwater resources based on GIS. - Advances in water science 14(3): 358-362.

[6] Wang, L. Z. (2004): Optimal allocation model of water resources in the People's Victory Canal Irrigation District. - Yellow River 26(9): 26-28.

[7] Su, S., Lin, A. W., Liu, Q. H. (2004): Ordinary kriging algorithm applied for interpolation. - Journal of Southern Yangtze University (Natural Science Edition) 3(1): $18-21$.

[8] Li, X., Cheng, G. D., Lu, L. (2000): Comparison of spatial interpolation methods. - Advance in Earth Sciences 15(3): 260-264.

[9] Jin, G. D., Liu, Y. C., Niu, W. J. (2009): Comparison between inverse distance weighting method and kriging. - Journal of Changchun University of Technology 24(3): 53-57.

[10] Chen, W. (2011): The application of rank correlation anslysis on the evaluation of trends in the pore groundwater level changes in Huaibei Plain, Anhui Province. - Hydrogeology \& engineering geology 38(1): 35-39.

[11] Jiang, Q. (2013): Comparison of spatial interpolation methods for groundwater depth in Shule River Basin. - Water Saving Irrigation (7): 62-64.

[12] Liu, K., Cui, C. F., Jiang, H. X. (2013): Study on spatial distribution law of groundwater level in Xianyang city based on GIS software. - Water saving irrigation (4): 42-45, 49.

[13] Liu, Z. L. (2013): Environmental Kuznets Curve: A New Computational Test and Modeling. - IJACT 5(5): 551-558.

[14] Li, D. Li., Wu, J. Q., Peng, W. X., et al. (2015): Effect of lignin on bamboo biomass 
self-bonding during hot pressing: lignin structure and characterization. - BioResources 10(4): 6769-6782.

[15] Ge, S. B., Peng, W. X., Li, D. L.,et al. (2015): Study on antibacterial molecular drugs in Eucalyptus granlla wood extractives by GC-MS. - Pak. J. Pharm. Sci. 28(4): 1445-1448.

[16] Yu, L. L., Li, J. H., Shi, C. J. (2015): Modeling of acoustic field for a parametric focusing source using the spheroidal beam equation. - Polish Maritime Research 22, Special Issue S1 (86): 43-47.

[17] Yu, Z. G., Chen, R. R., Mtei, B. (2016): Study on corrosion and destroy mechanism of concrete under acidic conditions. - Journal of Mechanical Engineering Research and Developments 39(1): 142-148. 